\title{
THE IMPROVING OF HIGHER-ORDER THINKING SKILLS AS INFORMATION FILTER FOR ALPHA GENERATION
}

\author{
Weni Tria Anugrah Putri ${ }^{1}$, Restu Yulia Hidayatul Umah ${ }^{2}$
}

\author{
IAIN Ponorogo, Indonesia ${ }^{1,2}$ \\ E-mail: wtriaanugrahputri@iainponorogo.ac.id ${ }^{1}$, umah@iainponorogo.ac.id ${ }^{2}$
}

DOI: $\underline{10.14421 / a l-b i d a y a h . v 12 i 1.341}$

\begin{abstract}
This paper's aim is to describe the strategy to improve the ability to think at a higher level for children currently in primary education. Children currently in primary education are children who are in the Alpha generation. This generation is certainly different from previous generations, especially in access to information. Even children holding a device in daily life is not a strange sight. This fact needs to be examined more about the balance in the speed of obtaining information and managing it. The more accessible access to information is, the expectation is children have a good filter for news or information that is classified as reasonable and vice versa, namely information that is classified as not making sense. The ability to filter this information is not easily obtained by every child. In other words, children need a stimulus to be able to think at a high level. The goal is that when children can think at a high level, then that ability is used as a weapon to gain the ability to filter information. In this paper, the focus of discussion is a strategy that should be taught by adults around the children to be able to be wiser in managing information. This research applies a qualitative approach with a literature study. The finding is the ability for the children to think at a higher level can improve with learning through contextual problems. This contextual problem is obtained from daily activities carried out by children.
\end{abstract}

\section{Keywords: alpha generation; the filtering of information; HOTS}

\section{INTRODUCTION}

The ability to think at a higher level is an essential skill in recent years. ${ }^{1}$ This ability also extends to children who have been able to do it. Not something new anymore in the learning and research on education; this high-level thinking study becomes one of the interesting problems.

This study is about a grade of elementary school-age children. At present, elementary school ages begin to be dominated by the alpha generation. Alpha generation is a generation that was born starting in $2010 .^{2}$ If examined further, this generation is already in grade 3 elementary school. This generation refers to the age of elementary school children aged seven, eight, and nine years. In these periods, children can do higherorder thinking. ${ }^{3}$ It is in these elementary school ages that children should get the

${ }^{1}$ Alice Thomas dan Glenda Thorne, "How To Increase Higher Level Thinking," The Center for Development \& Learning, December 7, 2009, https://www.cdl.org/how-to-increase-high-order-thinking/.

${ }^{2}$ Yanuar Surya Putra, "Theoritical Review : Teori Perbedaan Generasi," Among Makarti 9, no. 2 (May 3, 2017), https://doi.org/10.52353/ama.v9i2.142.

3 Thomas dan Thorne, "How To Increase Higher Level Thinking." 
stimulation and teaching with this high-level thinking ability. Children who can think at a higher level can recognize patterns of relationship to incoming information. ${ }^{4}$ How children can recognize patterns of relationships, means children have obtained some experiences. These experiences are the starting point for children to be able to develop their next abilities.

Even children after recognizing the relationship, patterns of experience, can structure based on specific classifications. When playing marbles together, children learn from the losses they endured. Children learn the characters and the way friends play in their groups. The ability to learn this character refers to the ability to think at a higher level that is naturally done by children. The character and how to play marbles by friend A seems different from playing friend B. Children are anticipating something to be released from a problem or winning the game. ${ }^{5}$

The confusion of the children with the characters of their peers in play can make children learn how to ask questions and identify things that raise questions. The experience provides good learning when children begin to go into the details in it. To be able to enter his experience, it requires thinking at a high level. When children can think at a higher level, the child can solve problems, think critically, creatively, and be able to make decisions. ${ }^{6}$

Newman and Wehlage in Ahmadi and Widodo stated, children who can think at a high level should ideally give good arguments. ${ }^{7}$ The ability to argue is needed, given that there is something that needs to be fought by every individual. Good arguments contain reasons that are objective and are acceptable to reason. To be able to argue well, it takes so much information that has been patterned by someone. One aim is to support the argument.

Based on the explanation above, not all children who have the ability to think at a high level have been responded to by adults around them. How not, naturally, children learn things around them and make them children with the ability to reason. Stepping on

${ }^{4}$ Lorin W. Anderson et.al., Kerangka Landasan untuk Pembelajaran, Pengajaran, dan Asesmen: Revisi Taksonomi Pendidikan Bloom, Translated by: Agung Prihantoro (Yogyakarta: Pustaka Pelajar, 2015).

5 Thomas dan Thorne, "How To Increase Higher Level Thinking."

${ }^{6}$ I Wayan Widana, Modul: Penyusunan Soal Higher Order Thinking Skill (HOTS) (Jakarta: Direktorat Pembinaan SMA Direktorat Jenderal Pendidikan Dasar dan Menengah Departemen Pendidikan dan Kebudayaan, 2017).

${ }^{7}$ Abu Ahmadi dan Supriyono Widodo, Psikologi Belajar (Jakarta: Rineka Cipta, 2013). 
the school stage, not all teachers respond to the natural side of children in thinking and reasoning. ${ }^{8}$ The prove is by the questions from the teacher to students who are low in quality of thinking. The way to get children to work on problems with low-quality thinking will make them accustomed to thinking at a low level. ${ }^{9}$

One astonishing fact is that the lack of interest in reading children will further plunge it into hoax information. The survey by PISA in 2018, Indonesia was ranked 72 of 78 countries in reading skills. ${ }^{10}$ The more often read literacy, the better the way someone is filtering the incoming information

Based on the explanation above, what is needed is support from the adults around the child to help him keep thinking at a high level? Are these activities assistance or support varies? Some of them started from playing activities to giving questions with high quality. On this occasion, the authors offer several ways as adult support to be able to support the children's natural abilities. The adults in question are parents, teachers or other adults in the vicinity. Thus the author intends to play tricks to be able to keep children thinking at a higher level. Of course this high level of thinking acts as a weapon to be able to think critically, creatively, and be able to make decisions. The overall effect is that children can filter various incoming information.

\section{RESEARCH METHODS}

The research in this article used a qualitative approach. ${ }^{11}$ The design of this study applied library research. This research data came from primary literature sources, both from journal articles, proceedings, and books that study the stimulation of higher-order thinking skills for children, as well as themes related to the use of higher thinking skills as a means to filter information in the digital era. The research analysis uses three processes, namely data reduction, data display, and conclusion drawing, where the typing takes place interactively.

\footnotetext{
${ }^{8}$ Atena Danner, "How Positive \& Negative Climate Among Teachers Affect Children," 2019, http://info.teachstone.com/blog/how-positive-negative-climate-among-teachers-affect-children.

${ }^{9}$ Editorial Team, "How to Improve Thinking Skills of a Child," GetLitt! (blog), 17 April 2019, https://www.getlitt.co/blog/how-to-improve-thinking-skills-of-a-child/.

${ }^{10}$ OECD, PISA 2018 Results Combined Executive Summaries Volume I, II, \& IIII (Paris, France: OECD Publishing, 2019).

11 Sugiyono, Metode Penelitian Pendidikan (Pendekatan Kuantitatif, Kualitatif dan R\&D) (Bandung: Alfabeta, 2013), 8.
} 


\section{RESULT AND DISCUSSION}

\section{Overview of High-Level Thinking Concepts}

High-level thinking is one of the Bloom ideas. Clearly, there are three significant levels of this classification, namely low, medium, and high-level thinking abilities. Even so, Bloom stated that there are six levels of thinking. Figure 1 showed Bloom's cognitive level.

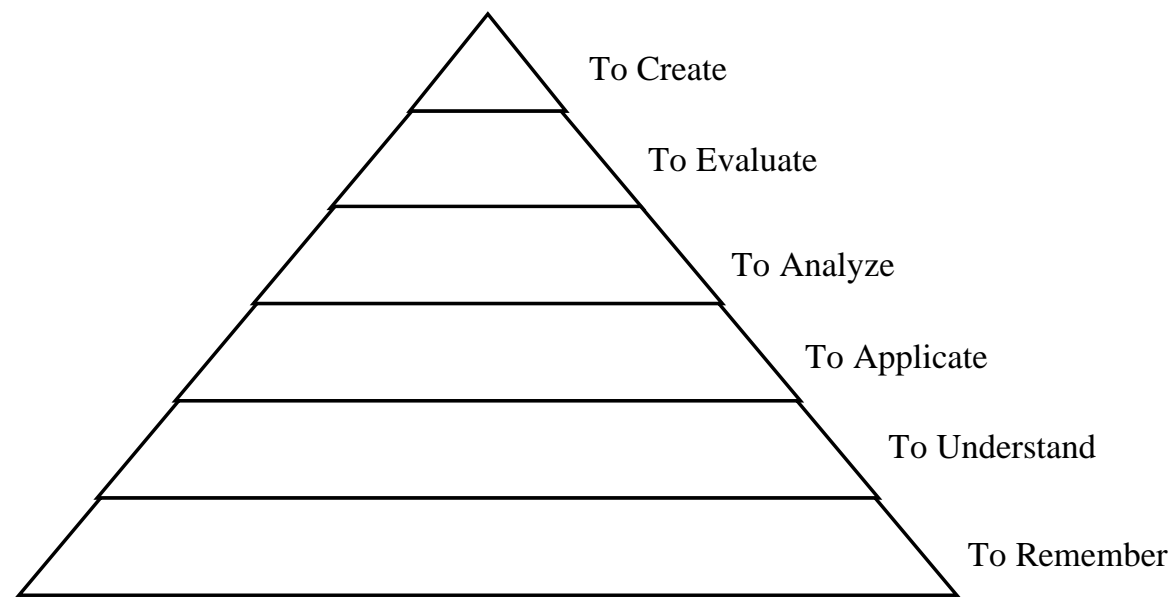

Figure 1

Bloom's Cognitive Ability Levels ${ }^{12}$

Based on Figure 1, someone who can remember that is far more than someone who can be creative. People who can be creative are people who have been able to pass the previous stages. The first is the remembering level. This level is an activity to regain the desired knowledge from memory. ${ }^{13}$ Remember to be the most basic level because in this process is the easiest. The teachers applied many questions to their students are still compartmentalized at this level.

The second is understanding level. This level is higher than in the first stage. This stage relates to the ability to interpret things. One of the indicators of understanding levels is if students can connect the newly acquired knowledge with their old knowledge. ${ }^{14}$ In other words, the teachers ask students or children to tell under their respective imaginations. Thus undoubtedly different from one child with another related to their

12 Anderson et.al.., Kerangka Landasan untuk Pembelajaran, Pengajaran, dan Asesmen: Revisi Taksonomi Pendidikan Bloom, Translated by: Agung Prihantoro.

${ }^{13}$ Wowo Sunaryo Kuswana, Taknsonomi Berpikir (Bandung: Remaja Rosdakarya, 2012).

${ }^{14}$ L.W. Anderson dan D.R. Krathwohl, Pembelajaran, Pengajaran dan Asesmen (Revisi Taksonomi Pendidikan Bloom) (Yogyakarta: Pustaka Pelajar, 2009). 
ability to understand. In the test, the indicators for the second level are students must be able to compare, summarize, explain, characterize, and estimate.

The third is the application level. This level is the process of bringing or carrying out a procedure into tasks that have been identified previously and using that procedure into tasks that are not yet recognized. ${ }^{15}$ Children who start learning to read will make it remember the letters. Unlike when a child can read and even uses intonation, the child no longer only remembers letters. Reading is the process of applying children's understanding.

The fourth is the analyzing level. This stage includes the process of differentiating, organizing, and attributing. This analysis activity involves the process of breaking down or breaking down a problem into parts and determining how the relationships between the parts as a whole. ${ }^{16}$ In other words, in this process, children are asked to break down information into specific classifications. Not surprisingly, when playing jump rope, a child will conclude that friend $\mathrm{A}$ is hard to beat with several arguments in his favor.

The fifth is the evaluating level. The indicator of evaluating level is assessing according to applicable standards. The evaluating category consists of the process of examining and criticizing. A group of children who are playing together has different views from one another. A child will classify his friends into certain classification forms. The point is that the class of friends who are hard to beat when playing jump rope, the group who is and who is very difficult to beat. ${ }^{17}$

In this study, which is included in the classification of high-level thinking is in the fifth and sixth levels. The low-level thinking stage or called as lower-order thinking skills (LOTS) is the first and second levels. The intermediate level thinking stages or called medium order thinking skills (MOTS) is the third and fourth levels. The higher-order thinking skills (HOTS) is the last two stages, the fifth and the sixth levels.

15 Herni Budiati, “Analisis Soal Ujian Nasional IPA SMP Tahun 2014 Berdasarkan Dimensi Pengetahuan Dan Dimensi Proses Kognitif," Proceeding Biology Education Conference: Biology, Science, Enviromental, and Learning 11, no. 1 (November 17, 2014): 1196-1201, https://jurnal.uns.ac.id/prosbi/article/view/8034.

16 Nurhayati Nurhayati and Lia Angraeni, "Analisis Kemampuan Berpikir Tingkat Tinggi Mahasiswa (Higher Order Thinking) Dalam Menyelesaikan Soal Konsep Optika Melalui Model Problem Based Learning," Jurnal Penelitian \& Pengembangan Pendidikan Fisika 3, no. 2 (December 30, 2017): 119-26, https://doi.org/10.21009/1.03201.

17 Anderson et.al., Kerangka Landasan untuk Pembelajaran, Pengajaran, dan Asesmen: Revisi Taksonomi Pendidikan Bloom, Translated by: Agung Prihantoro. 
The development of student's high-level thinking needs many supporting factors. One of them is to stimulate contextual problems. Contextual refers to problems that arise in everyday life. The five characteristics of how to test the ability of high-level thinking in children, namely: relating, experiencing, applying, communicating, transferring. ${ }^{18}$

When the teacher or parent stimulates and tests the ability to think at a higher level, it should be related to the context of the child's real-life experience. The providing of stimuli and testing to students has based on what children know is humane and undoubtedly able to measure more objectively. This activity is commonly referred to as relating. The reflection of the experiences appears in activities that inspire children to conduct experiments. This activity conditions the child as an inventor. This is in accordance with the stage of development of the child who always feels curious about things around them.

The implementation for applying levels is such as children who must be able to use their knowledge to solve their problems. The learning will not become effective if learning does not make students able to use their knowledge in daily life. Communicating refers to stimulating and testing children to be able to communicate and argue well with the results of their learning activities. Transferring refers to the use of knowledge that has been obtained in other contexts that are considered relevant. Naturally, children often use pomelo orange peels to make tires for cars. Simply stated, this is the transferring process of the child's imagination.

\section{The Alpha Generation}

The concept of alpha generation describes the smartest generation among previous generations. Alpha generation also called "A" generation. This generation appears after generation Z. In general, people will say that generation A is a child of the millennial generation (generation Y). Generation A is the generation that was born after $2010 .{ }^{19}$ That is what causes Generation A to have a character similar to its parents. Generation A is the generation that is the target of marketing for several industries. ${ }^{20}$ It is not wrong if many

${ }^{18}$ Kokom Komalasari, Pembelajaran Kontekstual (Bandung: Refika Aditama, 2010), 13.

19 Sigit Purnama, U Sunan, and K Yogyakarta, "Pengasuhan Digital Untuk Anak Generasi Alpha," Al Hikmah Proceedings on Islamic Early Childhood Education 1, no. 1 (2018): 493-502, https://www.academia.edu/download/57365843/Pengasuhan_Digital_48_Sigit_Purnama_493-502.pdf.

20 Khumo Theko, "Meet Generation Alpha," Informasi, Fluxtrends (blog), 2019, https://www.fluxtrends.com/meet-generation-alpha/. 
mothers from the millennial generation are often willing to buy expensive clothes to meet the needs of their children (generation A).

Generation $\mathrm{A}$ is the generation that has always been most familiar with the internet and digital technology; Widodo and Rofiqoh stated that this generation was the most intelligent compared to previous generations. ${ }^{21}$ Why is that? A simple example is the use of devices by children of this generation even though they just woke up. Children of this generation tend to be inseparable from gadgets. There is a news that had horrendous cyberspace that is the mother who put on her children's eyes with makeup to make it look black. The mother's goal is for the child to reduce the intensity of playing the device. ${ }^{22}$ Nevertheless, these actions are still reaping the pros and cons.

How is this generation called the Alpha generation? Initially, scientists felt they had used the alphabet to the letter $\mathrm{Z}$. That was the basis for using the Greek letters and finally followed by sociologists to follow it. ${ }^{23}$ Generation A is a generation that has been exposed to the effects of devices early on. It is not wrong if this generation is a generation that tends to be individualistic. Children begin to start looking at the device from hour to hour regardless of the presence of others. Even the current Governor of East Java says that this generation is an anti-social generation ${ }^{24}$. This generation has a tendency to ignore social relations and tend to prefer one thing, namely "gadget".

Purnama summarizes many Alpha generation characters, including (1) High dominance, (2) difficult to share, (3) difficult to follow the rules, (4) difficult regardless of technology, and 5) less communicative. ${ }^{25}$ Table 1 shows the difference between this generation and the previous generation.

${ }^{21}$ Ganjar Setyo Widodo and Kharisma Sita Rofiqoh, "Pengembangan Guru Profesional Menghadapi Generasi Alpha," Jurnal Ilmiah Pendidikan Citra Bakti 7, no. 1 (March 31, 2020): 13-22, https://doi.org/10.38048/jipcb.v7i1.67.

${ }^{22}$ Aisyah Kamaliah, "Viral Kisah Anak 'Mata Hitam’ Karena Keseringan Main Ponsel,” Informasi, Detikinet (blog), 2019, https://m.detik.com/inet/cyberlife/d-4624622/viral-kisah-anak-mata-hitam-karenakeseringan-main-ponsel.

${ }^{23}$ M McCrindle, The ABC of XYZ (Australia: UNSW, 2011).

${ }^{24}$ Marrisa Indrayana, Hendro Aryanto, and Aniendya Christianna, "Perancangan Buku Interaktif Pembelajaran Pengembangan Karakter Pada Generasi Alfa," Jurnal DKV Adiwarna 1, no. 12 (July 20, 2018): 10, http://publication.petra.ac.id/index.php/dkv/article/view/7511.

${ }^{25}$ Purnama, "Pengasuhan Digital untuk Anak Generasi Alpha." 
Table 1

Comparison of Z Generation with Alpha Generation

\begin{tabular}{cll}
\hline Generation & Period & \multicolumn{1}{c}{ Character } \\
\hline $\begin{array}{c}\text { Generation } \\
\text { Z }\end{array}$ & $\begin{array}{c}1995- \\
2010\end{array}$ & $\begin{array}{l}\text { Able to do several activities at one time. Tends to be } \\
\text { individualistic. More creative than the previous generation. }\end{array}$ \\
\hline $\begin{array}{c}\text { Alpha } \\
\text { generation }\end{array}$ & $\begin{array}{c}2011- \\
2025\end{array}$ & $\begin{array}{l}\text { Most understand technology. This generation is considered } \\
\text { the most intelligent among previous generations. }\end{array}$
\end{tabular}

\section{Information Filtering Capabilities}

Information is a result of processing data that is claimed to be important for its users and becomes the basis for determining a decision ${ }^{26}$. Because there is a processing stage, there is data in the information that may be reduced by the recipient. A child who likes holidays will tend to store memory information about activities on holiday. Information about the tasks that accompany it on holidays may be forgotten. ${ }^{27}$

How can information be able to increase knowledge? The information is to whatever is received by the human senses. Every day millions of information are ready to be received. Information can reduce uncertain things, such as teachers who do not enter and cannot teach so that children are closed. This uncertainty is intended as the benefit of information.

The benefits of having the information filter skills for children are children can choose and sort factual information. This information will later be used by children to make decisions. This data is following the news that blows in 2018; some teenagers committed suicide in Blitar. ${ }^{28}$ The cause of the suicide is a family problem. The main focus is the ease with which reckless actions are carried out, given the child's future is still long. This event is also influenced by the information they get. In effect, the teenager made it his decision. Even though the generation is generation $\mathrm{Z}$, but what about generation A, which the information flow will be faster later. So that information filters should be taught and not cause similar events in the next generation.

${ }^{26}$ Pawit M. Yusuf, Ilmu Informasi, Komunikasi, dan Kepustakaan, I (Jakarta: Bumi Aksara, 2009), 31.

${ }^{27}$ Sutanta, Sistem Informasi Manajemen, 10.

${ }^{28}$ Solichan Arif, “Lagi, Remaja Putri di Blitar Bunuh Diri Tinggalkan Surat,” Informasi, Sindo News (blog), 2018, https://daerah.sindonews.com/newsread/1310607/23/lagi-remaja-putri-di-blitar-bunuh-diritinggalkan-surat-1527779481. 


\section{The Strategies for Utilizing Higher-Order Thinking Abilities to Filter Information}

The ability to think at a higher level is at C5 (evaluation) and C6 (creation). This ability to think is associated with contextual learning assessment. What the presenter believes is that children will quickly think at a high level if supported by contextual matters. Thus the higher-order thinking ability is related to the contextual assessment described in the previous sub-chapter. In this study referred to as REACT. To stimulate children to think at a high level during the evaluation phase, especially to be able to filter information, i.e:

The first is at the C5 level, parents or teachers can provide a contextual problem to the child. The child is asked to be able to evaluate a problem using simple language. If, based on the criteria of contextual learning assessment, the details of the assessment are as follows: in the relating stage, the child learning material being studied is then linked to prior knowledge or experiences from real life. ${ }^{29}$ The activities of the children can stimulate them. It is not recommended to test the child if it has nothing to do with the activities he does every day. Such as games, children get so much learning from these activities. The operational verb that can be used to stimulate and test this stage is 'clarifying'. That is, parents must stimulate children to be able to clarify the information they have obtained. This clarifying activity is carried out by children when there is information that is felt to be unclear. For example, when children are given information about the rules of the jump rope game. The teacher or parent can ask the child to repeat and clarify the rules. The question "is there anything unclear?" seems able to inspire children to dare to ask. For stage C6 children can be stimulated with questions about 'linkages'. In learning, the teacher is not wrong if they asked to the children about the relationship of the game with the books he has read.

At the experiencing stage, the teacher gives the children an explanation that leads to the discovery of new knowledge. ${ }^{30}$ Children can be stimulated by asking children to do certain activities. If the activity intended is play, then it can be done experimentally

${ }^{29}$ Fitriya Karima and Kasmadi Imam Supardi, "Penerapan Model Pembelajaran MEA Dan REACT Pada Materi Reaksi Redoks," Jurnal Inovasi Pendidikan Kimia 9, no. 1 (2015), https://journal.unnes.ac.id/nju/index.php/JIPK/article/view/4810.

30 S Siradjuddin, Haris Rosdianto, and Emi Sulistri, "Penerapan Model REACT Untuk Meningkatkan Keterampilan Proses Sains Siswa Pada Materi Arus Listrik," Jurnal Pendidikan Fisika Dan Keilmuan (JPFK) $\quad 4, \quad$ no. $\quad 1 \quad$ (2018): https://www.academia.edu/download/60034294/2018_JPFK_Vol.4_No.120190717-130018-5kv6re.pdf. 
and ask children to predict. For stage C5, parents can ask children to judge who will be the winner when the game is in the middle of the road. The question such as "Who should be the winner?" can inspire children to analyze according to the study in C5. For stage C6, children can be asked about how to cope with or overcome defeat. Of course, every child wants to be a winner in a game. Easy questions like 'how can you not lose?' It can stimulate children to experiment using specific techniques from the results of their thinking.

The applying level is a stage that students do the implementatation of the concepts. ${ }^{31}$ At this stage, the children get stimulation from the educator. The step to simulation is by asking the child to stop for a moment in the game. The teacher or parent can ask the child to write or draw in a sketch of who is the winner or loser in the current game. The operational verb used is, for example, 'rank'. On a piece of paper, the child is asked to write down a ranking that is approximately obtained by each player. While at stage C6, children can get a stimulus to 'design' how to become a winner. Parents can give it an extra sheet of paper to write this down.

The parents can stimulate children to be able to explain their arguments, such as by the question, "Why are you choosing friend A as winner and friend B as the loser?". This study used the operational verb is "justifying". The teacher or parents can ask the children to argue well armed with the information. The way for argumentative children is to allow them to explain at length about what he already knows. ${ }^{32}$ For the C6 stage, the teacher or parents can stimulate the children by asking them to create a game flow that will later allow him to become a winner.

At the transferring stage, the children use the newly acquired knowledge to deal with the situation he just experienced. ${ }^{33}$ The teacher can teach or stimulate the children through their predictions in other different games. The teacher has to prepare a different game from the current game. The teacher can give a stimulating to children to 'predict' about the winner of the next game. Then, in the sixth level (C6), the teacher can give a

\footnotetext{
Redoks."

${ }^{31}$ Karima dan Supardi, "Penerapan Model Pembelajaran MEA dan REACT pada Materi Reaksi

32 C.J. Simister, Anak- anak Cemerlang, trans. oleh Amanda Setyorini (Jakarta: Serambi Ilmu Semesta, 2009), 171.

${ }^{33}$ A. T. Arifin, Kartono Kartono, and Hery Sutarto, "Keefektifan Strategi Pembelajaran React Pada Kemampuan Siswa Kelas VII Aspek Komunikasi Matematis," Kreano, Jurnal Matematika Kreatif-Inovatif 5, no. 1 (June 22, 2014): 91-98, https://doi.org/10.15294/kreano.v5i1.3282.
} 
stimulating to the children in the form of development from the results of their predictions if they are able. If the child can predict a thing, then the teacher can ask the child to develop predictions that are associated with themselves. The teacher has to develop the previously designed design in written or oral form in a clear and detailed manner.

Every child has a natural ability to think at a high level. The adults around them have to provide the right stimulus so that the information that enters the children is positive information. In the end the children will easily argue with good quality. Supervision from parents or teachers is also one of the things that is useful so that children will only absorb positive information.

\section{Some Activities to Teach Children to Filter the Information}

To be able to realize the above explanation, some games can stimulate children to think higher level. The first game is the opening your eyes, open your mind. Simister stated, armed with the device that the children have and are being liked by the children, then ask questions: (1) things that must be true are known, (2) things that might be true, and how to find out, (3) things that he wants to know. ${ }^{34}$

The second game is called "I have a problem". This game aims to develop the ability to make wise decisions. ${ }^{35}$ On this occasion, the presenter media combined the game with the ability to think at a higher level in children. Teachers or parents can provide simple problems such as what if your bike is broken what will be done? Then, the teacher asks each student by taking turns about the solution that will be decided. The teacher also asks questions about the kinds of information that support the decision. The students answer on paper. Solutions must be more than one. At the end of the game, the teacher asks students to name the funniest and most sensible ideas.

The third game is the Mysterious Route. This game was initially used to improve problem-solving skills. ${ }^{36}$ The presenter combines it with the children's ability to think at a higher level. The first step is to determine a route, for example, a route home from school. The teacher asks students to write down many routes that are known to students. The number of routes is a way to explore information that is known by students. The more routes are written down, the more information students have.

\footnotetext{
${ }^{34}$ Simister, Anak- Anak Cemerlang.

${ }^{35}$ Simister.

${ }^{36}$ Simister.
} 


\section{CONCLUSION}

The children's ability to think at a higher level is to be a natural action. Especially by the alpha generation that incidentally, the information flow is getting faster. The effect obtained is the more creative children in the future. The " $\mathrm{A}$ " generation is the smartest generation among all generations. At present, the first generation of this generation is already in grade 3 elementary school or around the age of nine years.

Children in the "A" generation can not seem to be separated from the device so that learning must be paid more attention. This condition is certainly different from learning in previous generations. Good learning is learning that keeps getting used to high-level thinking. One of the methods used is learning through contextual problems. This contextual problem is obtained from daily activities carried out by children.

Based on the findings of this study, future research on developing higher-order thinking skills as a filter for information for students can be continued with field research with the object of study in elementary school or the life of elementary school-age children on diverse social, economic and geographical background conditions. In addition, researchers in the future can continue the study of the development of media or teaching materials on various contextual digital games or digital culture-based digital games.

\section{REFERENCES}

Ahmadi, Abu, dan Supriyono Widodo. Psikologi Belajar. Jakarta: Rineka Cipta, 2013.

Anderson, Lorin W., David R. Krathwohl, Peter W. Airasian, Kathleen A. Cruikshank, Richard E. Mayer, Paul R. Pintrich, James Raths, dan Merlin C. Wittrock. Kerangka Landasan untuk Pembelajaran, Pengajaran, dan Asesmen: Revisi Taksonomi Pendidikan Bloom, Translated by: Agung Prihantoro. Yogyakarta: Pustaka Pelajar, 2015.

Anderson, L.W., dan D.R. Krathwohl. Pembelajaran, Pengajaran dan Asesmen (Revisi Taksonomi Pendidikan Bloom). Yogyakarta: Pustaka Pelajar, 2009.

Arif, Solichan. "Lagi, Remaja Putri di Blitar Bunuh Diri Tinggalkan Surat." Informasi. $\begin{array}{lll}\text { Sindo News } & \text { (blog), }\end{array}$ https://daerah.sindonews.com/newsread/1310607/23/lagi-remaja-putri-di-blitarbunuh-diri-tinggalkan-surat-1527779481.

Arifin, A. T., Kartono Kartono, and Hery Sutarto. "Keefektifan Strategi Pembelajaran React Pada Kemampuan Siswa Kelas VII Aspek Komunikasi Matematis." Kreano, Jurnal Matematika Kreatif-Inovatif 5, no. 1 (June 22, 2014): 91-98. https://doi.org/10.15294/kreano.v5i1.3282.

Budiati, Herni. "Analisis Soal Ujian Nasional IPA SMP Tahun 2014 Berdasarkan Dimensi Pengetahuan Dan Dimensi Proses Kognitif." Proceeding Biology 
Education Conference: Biology, Science, Enviromental, and Learning 11, no. 1 (November 17 , 2014):

1196-1201, https://jurnal.uns.ac.id/prosbi/article/view/8034.

Danner, Atena. "How Positive \& Negative Climate Among Teachers Affect Children," 2019. http://info.teachstone.com/blog/how-positive-negative-climate-amongteachers-affect-children.

Editorial Team. "How to Improve Thinking Skills of a Child." GetLitt! (blog), 17 April 2019. https://www.getlitt.co/blog/how-to-improve-thinking-skills-of-a-child/.

Indrayana, Marrisa, Hendro Aryanto, and Aniendya Christianna. "Perancangan Buku Interaktif Pembelajaran Pengembangan Karakter Pada Generasi Alfa." Jurnal DKV Adiwarna 1, no. 12 (July 20, 2018): 10 , http://publication.petra.ac.id/index.php/dkv/article/view/7511.

Kamaliah, Aisyah. "Viral Kisah Anak 'Mata Hitam' Karena Keseringan Main Ponsel." Informasi. Detikinet (blog), 2019. https://m.detik.com/inet/cyberlife/d4624622/viral-kisah-anak-mata-hitam-karena-keseringan-main-ponsel.

Karima, Fitriya, and Kasmadi Imam Supardi. "Penerapan Model Pembelajaran MEA Dan REACT Pada Materi Reaksi Redoks." Jurnal Inovasi Pendidikan Kimia 9, no. 1 (2015). https://journal.unnes.ac.id/nju/index.php/JIPK/article/view/4810.

Komalasari, Kokom. Pembelajaran Kontekstual. Bandung: Refika Aditama, 2010.

Kuswana, Wowo Sunaryo. Taknsonomi Berpikir. Bandung: Remaja Rosdakarya, 2012.

McCrindle, M. The ABC of XYZ. Australia: UNSW, 2011.

Nurhayati, Nurhayati, and Lia Angraeni. "Analisis Kemampuan Berpikir Tingkat Tinggi Mahasiswa (Higher Order Thinking) Dalam Menyelesaikan Soal Konsep Optika Melalui Model Problem Based Learning." Jurnal Penelitian \& Pengembangan Pendidikan Fisika 3, no. 2 (December 30, 2017): 119-26. https://doi.org/10.21009/1.03201.

OECD. PISA 2018 Results Combined Executive Summaries Volume I, II, \& IIII. Paris, France: OECD Publishing, 2019.

Purnama, Sigit, U Sunan, and K Yogyakarta. "Pengasuhan Digital Untuk Anak Generasi Alpha." Al Hikmah Proceedings on Islamic Early Childhood Education 1, no. 1 (2018):

493-502, https://www.academia.edu/download/57365843/Pengasuhan_Digital_48_Sigit_ Purnama_493-502.pdf.

Putra, Yanuar Surya. "Theoritical Review : Teori Perbedaan Generasi." Among Makarti 9, no. 2 (May 3, 2017). https://doi.org/10.52353/ama.v9i2.142.

Simister, C.J. Anak- anak Cemerlang. Diterjemahkan oleh Amanda Setyorini. Jakarta: Serambi Ilmu Semesta, 2009.

Siradjuddin, S, Haris Rosdianto, and Emi Sulistri. "Penerapan Model REACT Untuk Meningkatkan Keterampilan Proses Sains Siswa Pada Materi Arus Listrik." Jurnal Pendidikan Fisika Dan Keilmuan (JPFK) 4, no. 1 (2018): 17-22, https://www.academia.edu/download/60034294/2018_JPFK_Vol.4_No.1201907 17-130018-5kv6re.pdf. 
Sugiyono. Metode Penelitian Pendidikan (Pendekatan Kuantitatif, Kualitatif dan R\&D). Bandung: Alfabeta, 2013.

Sutanta, Edhy. Sistem Informasi Manajemen. Yogyakarta: Graha Ilmu, 2003.

Theko, Khumo. "Meet Generation Alpha." Informasi. Fluxtrends (blog), 2019. https://www.fluxtrends.com/meet-generation-alpha/.

Thomas, Alice, dan Glenda Thorne. "How To Increase Higher Level Thinking." The Center for Development \& Learning, 7 December 2009. https://www.cdl.org/how-to-increase-high-order-thinking/.

Widana, I Wayan. Modul: Penyusunan Soal Higher Order Thinking Skill (HOTS). Jakarta: Direktorat Pembinaan SMA Direktorat Jenderal Pendidikan Dasar dan Menengah Departemen Pendidikan dan Kebudayaan, 2017.

Widodo, Ganjar Setyo, and Kharisma Sita Rofiqoh. "Pengembangan Guru Profesional Menghadapi Generasi Alpha." Jurnal Ilmiah Pendidikan Citra Bakti 7, no. 1 (March 31, 2020): 13-22. https://doi.org/10.38048/jipcb.v7i1.67.

Yusuf, Pawit M. Ilmu Informasi, Komunikasi, dan Kepustakaan. I. Jakarta: Bumi Aksara, 2009. 